\title{
Realising the Vision of Technology Integration: A Case Study of K-I2 Private Schools in the United Arab Emirates
}

\author{
Kheder Mahmoud ${ }^{\mathrm{I}}$, Catherine Arden², Jennifer Donovan ${ }^{3}$ \\ IDoctoral Candidate, Doctor of Education, University of Southern \\ Queensland, Toowoomba, Queensland, Australia. \\ ${ }^{2}$ Senior Lecturer in Adult and Vocational Education, School of Education, \\ University of Southern Queensland, Toowoomba, Queensland, Australia. \\ ${ }^{3}$ Lecturer (Education), School of Education, University of Southern \\ Queensland, Toowoomba, Queensland, Australia.
}

\begin{abstract}
Heralded by the release of government policies such as Vision 202I, the United Arab Emirates (UAE) has joined the worldwide impetus for the integration of Information Communications Technologies (ICTs) into its KI2 education system as a central plank of reforms to its economy and education system. This presents challenges for schools in both public and private sectors in the UAE as they strive to adhere to national government and local education authority guidelines and standards for educational innovation. Whilst the UAE Government has invested heavily to support technology integration in public schools, private schools must fund their own technology integration initiatives. In a context of strong growth in the private K-I2 sector and reported high teacher turnover rates, private school leadership faces particular challenges related to decision-making about investment in suitable technologies and support systems, including teachers' professional development. This chapter reports some preliminary findings from a qualitative case study investigating the teacher, school and system-wide factors impacting on technology integration in selected private schools located in four Emirates. The study combines policy analysis with semi-structured
\end{abstract}


interviews of a purposive sample of private school $\mathrm{K}-\mathrm{T} 2$ educators to yield a detailed understanding of the challenges faced by private sector UAE schools in implementing technology integration in response to national government policy directives. The findings will inform the development of an implementation framework providing guidance regarding critical success factors for effective technology integration in private schools with particular implications for school leadership and teachers' professional learning.

Keywords: Educational change, ICT, innovation, national education policy, private schools, professional development, teachers, technology, technology integration, UAE

Acknowledgments: The authors acknowledge the valuable feedback provided by the book chapter's two peer reviewers and also by our colleague, Professor Patrick Danaher, on early drafts of the chapter.

\section{Introduction}

The integration of digital technologies into schooling is a "complex process of educational change" that has been a feature of the education landscape in recent decades and one that continues to present challenges for ${ }_{2 \mathrm{I}}{ }^{\text {st }}$ century schools and educators globally (Tondeur, van Braak, Ertmer, $\mathcal{F}^{\circ}$ Ottenbreit-Leftwich, 20I6, p. 555). The current Covidig pandemic has brought these issues into sharp focus as schools, teachers, students and parents across the globe adapt to new models of teaching and learning that leverage digital technologies to enable continuity of education amidst school closures and other disruptions to daily life (UNESCO, 2020). According to the Orgagnisation for Economic and Cultural Development (OECD) (2019), the impact of integrating Information Communications Technologies (ICTs) into schooling can be considered in terms of:

- the mandate for technology integration with respect to the need for students to develop digital literacy and competencies in order to "flourish in the digital age" 
This is a limited preview of the chapter.

To read the full-text chapter, get access by purchasing this chapter or consider buying the complete book. If your library has subscription to EBSCOhost, the chapter including other chapters of the book can be accessed through your library.

This chapter is a part of the book, 'Innovations in Educational Leadership and Continuous Teachers' Professional Development' ISBN (paperback): 978-8I-948483-2-5; ISBN (ebook): 978-8I' $948483-3-2$

Book DOI: https://dx.doi.org/ro.46679/isbn9788194848325 Chapter DOI: https://dx.doi.org/I0.46679/isbn978819484832512 
to the "myth" of a values-neutral "technological imperative" (Hoffman, 2006, p. Io) which they claim is designed to serve the vested interests of those who stand to profit from the proliferation of educational technologies rather than, and possibly even at the expense of, those whose interests the education enterprise is meant to serve. Putting meaningful pedagogical innovations front and centre of technological integration in schools, as recommended by Tondeur et al. (20I7), serves as a guiding principle for school leadership moving forward into the post-Covidig era.

\section{References}

Abu Dhabi Education Council's e-Learning initiative. (20I3). In ADEC. Retrieved from https://www.adec.ac.ae/en/MediaCenter/News/Pages/

AdvancEd. (20I7). AdvancEd performance standards for school systems. Retrieved from https://www.advanc-ed.org/sites/default/files/documents/APS_Systems.pdf

AdvancEd. (2018). AdvancED policies and procedures for accreditation and certification. Retrieved from https://www.advanc ed.org/sites/default/files/documents/AdvancED-Policies-and-Procedures.pdf.

Alkhyeli, H., छ Van Ewijk, A. (2018). Prioritisation of factors influencing teachers' job satisfaction in the UAE. International Journal of Management in Educationı2(I), I24, ISSN: $1750385 \mathrm{X} ; \mathrm{I} 7503868$

Almekhlafi, A. G., छ Almeqdadi, F. A. (20I0). Teachers' perceptions of technology integration in the United Arab Emirates school classrooms. Educational Technology E' Society, I3 $_{3}$ ( ), I65-I75

Alsharief, T. (2018). Pre-service teachers' perceptions of the barriers to ICT ni noitargetni tuf riehture instructional practice in a Gulf State. (Doctoral dissertation, University of Liverpool, United Kingdom). Retrieved from: https://livrepository.liverpool.ac.uk/30266I7/I/Hooo25528_Sep20I8.PDF

Andersson, S. B. (2006). Newly qualified teachers' learning related to their use of information and communication technology: A Swedish perspective. British Journal of Educational Technology, 375), 665-682

Angélli Genlott, A., Grönlund, Å., छ Viberg, O. (2019). Disseminating digital innovation in school-leading second order educational change. Education and Information Technologies, doi.org/10.1007/s10639-019-09908-0

Archambault, L., छ Crippen, K. (2009). Examining TPACK among K-I2 online distance educators in the United States. Contemporary Issues in Technology and Teacher Education, 9(I), 7I-88. 
Atl, M., छ Guessoum, N. (20I0). eLearning in United Arab Emirates. In U. Demiray (Ed), E-Learning Practices. Turkey: Anadolu University

Beidas-Strom, S., Rasmussen, T. N.,छ Robinson, D. O. (20II). Gulf Cooperation Council Countries (GCC): Enhancing economic outcomes in an uncertain global economy. Retrieved from https://www.imf.org/external/pubs/ft/dp/20II/IIoImcd.pdf

Bowen, G. A. (2009). Document analysis as a qualitative research method. Qualitative Research Journal, 9(2), 2740. doi:10.3316/QRJo902027

Bradshaw, P., Twining, P., छै Walsh, C. (2012). The vital program: Transforming ICT professional development. American Journal of Distance Education, 26(2), 74-85

Braun V, EClarke, V.(2006).Using thematic analysis in psychology. Qualitative Journal of Research in Psychology 3, pp.77-Ior.

Buabeng-Andoh, C. (2012). Factors influencing teachers' adoption and integration of information and communication technology into teaching: A review of the literature. International Journal of Education and Development using Information and Communication Technology (IJEDICT),(8)ז, pp. 136-155

Clark, N. (20I4). The major international school curriculums. World Education News and Reviews. Retrieved from https://wenr.wes.org/20I4/07/the-major-international-schoolcurriculums.

Davis, H., Hartshorne, P., छ Ring, G. (20I0). Being an innovative teacher: Preservice teachers' conceptions of technology and innovation. International Journal of Education 2(I), I-28.

Dawson, K. (2006). Teacher inquiry: A vehicle to merge prospective teachers' experience and reflection during curriculum-based, technology-enhanced field experiences. Journal of Research on Technology in Education, 38(3), 265-292.

Department for Education. (2016). Standards for British schools overseas. Retrieved from https://assets.publishing.service.gov.uk/government/uploads/system/uploads/attac hment_data/file/572360/BSO_standards_23Novi6.pdf

DiPietro, M., Ferdig, R.E., Preston, M., छु Black, E.W. (2008). Best practices in teaching KI2 online: Lessons learned from Michigan Virtual School teachers. Journal of Interactive Online Learning, $7(\mathrm{I})$, 10-35.

Educational Profession Licensure. (2018). Teaching licensing system. United Arab Emirates Ministry of Education. Retrieved from: https://tls.moe.gov.ae/\#!/about.

Eom, S. B., छ' Wen, H. J. (2006). The determinants of students' perceived learning outcomes and satisfaction in university online education: An empirical investigation. Decision Sciences Journal of Innovative Education, 4(2), 215-235

Erstad, O., Eickelmann, B., EJ Eichhorn, K. (2015). Preparing teachers for schooling in the digital age: A meta-perspective on existing strategies and future challenges.

Education and Information Technology, 20(4),641-654

Gao, P., Choy, D., Wong, A. F., E Wu, J. (2009). Developing a better understanding of technologybased pedagogy. Australasian Journal of Educational Technology, 25(5), 714-730. 
Garrison, R. (2003). Cognitive presence for effective asynchronous online learning: The role of reflective inquiry, self-direction and metacognition. Retrieved from https://www.researchgate.net/publication/228585404_Cognitive_presence_for_eff ective_asynchronous_online_learning_The_role_of_reflective_inquiry_selfdirection_and_metacognition

General Assembly (20I5). Transforming our world: the 2030 agenda for sustainable development report no. A/RES/70/I. United Nations.

Ghavifekr, S., Kunjappan, T., Ramasamy, L., छ Anthony, A. (20I6). Teaching and learning with ICT tools: Issues and challenges from teachers' perceptions. Malaysian Online Journal of Educational Technology, 4(2), 38-57development report no. A/RES/7O/I. United Nations.

Gil-Flores, J., Rodríguez-Santero, J., छ Torres-Gordillo, J.J. (20I7). Factors that explain the use if ICT in secondary-education classrooms: The role of teacher characteristics and school infrastructure. Computers in Human Behavior, 68, 44I-449

Godwin, S. (2006). Globalization, education and emiratisation: A study of the United Arab Emirates. The Electronic Journal on Information Systems in Developing Countries EJISDC2入(I), pp. I-I4 http://www.ejisdc.org

Goodwin, A. L., Low, E. L., Ng, P. T., Yeung, A. S., E Cai, L. (20I5). Enhancing playful teachers' perceptionof ICT use in the classroom: The role of risk taking as a mediator. Australian Journal of Teacher Education, 40(4), I32-I49.

Gray, D. E. (20I4). Doing research in the real world. London: SAGE

Hew, K. F., छ Brush, T. (2007). Integrating technology into K-I2 teaching and learning: Current knowledge gaps and recommendations for future research. Educational Technology Research and Development, 55 (3), 223-252. doi:I0.1007/sII423-006-9022-5.

Höckel, K. (2015). Better skills, better jobs, better lives: A strategic approach to skills policies for the United Arab Emirates. OCED

Hoffman, B. (2006). When means become ends: Technology producing values. Seminar.net Media, Technology and Lifelong Learning, 2(2), I-I2. Retrieved from http://seminar.net/volume-2-issue-2-2006-previousissuesmeny-II4/66-when-meansbecome-ends-technology-producing-values

Horn, M., छ Staker, H. (20II). The rise of $K-I 2$ blended learning. Mountain View CA.: Innosight Institute

Hvidt, M. (2013). Kuwait programme on development, governance and globalisation in the Gulf States: Economic diversification in GCC countries: Past record and future trends. Retrieved from The London School of Economics and Political Science: http://eprints.lse.ac.uk/55252/

Jigsaw Consult. (2016). MBRSLP research report 20I5 - 20I6. London: Author

Kamal, K., छ Trines, S. (2018, August 10). Education in the United Arab Emirates.

Education system profiles. Retrieved from:

https://wenr.wes.org/2018/o8/education-in-the-united-arab-emirates 
Kay, R. H., छै Knaack, L. (2005). A case for ubiquitous, integrated computing in teacher education. Technology, Pedagogy and Education, I4(3), 39I-4I2

Kingdom of Saudi Arabia. (2016). Vision 2030 Kingdom of Saudi Arabia. Kingdom of Saudi Arabia: Author.

Kozma, R. B. (2003a). ICT and education: A global phenomenon. In R. B. Kozma (Ed.). Technology, innovation, and educational change: A global perspective. Eugene, OR: International Society for Technology in Education (pp. I $>$ I8)

Kozma, R. B. (2003b). Technology and classroom practices: An international study. Journal of Research on Technology in Education, 36(I), I-I4.

Kozma, R. B. (Ed.). (2003c). Technology, innovation, and educational change: A global perspective. Eugene, OR: International Society for Technology in Education.

Kuwait. (20I7). New Kuwait 2035 Kuwait national development plan. Kuwait: Author.

Maceda, C. (20I7, July 3). UAE school fees 'second highest in the world': HSBC study. Retrieved from http://gulfnews.com/business/money/uae-school-fees-secondhighest-in-the-world-hsbc-study-1.2052333

Mohebi, L. (20I9). Leaders' perception of ICT integration in private schools: An exploratory study from Dubai (UAE).Social Science Research Network,Elsevier. Retrieved from https://www.researchgate.net/publication/333994622_LeadersPerceptionLeadersP erception_of_ICT_Integration_in_Private_Schools_An_Exploratory_Study_from _Dubai_UAE

National Qualifications Authority. (2015). Teacher standards for the UAE. United Arab Emirates. Retrieved from https://tls.moe.gov.ae/\#!/downloads-v2.

New England Association of Schools and Colleges. (20I9). Accreditation handbook 2019. Retrieved from https://cpss.neasc.org/sites/cpss.neasc.org/files/Downloads_pdf/20I9_Accreditati on_Handbook.pdf.

OECD. (2018). Trends shaping education 2018 spotlight 15: A brave new world. Retrieved from $\llbracket$ https://www.oecd.org/education/ceri/Spotlight-I5-A-Brave-New-WorldTechnology-and-Education.pdf].

OECD (20I9).TALIS 2018 Results (Volume I): Teachers and School Leaders as Lifelong Learners. OECD Publishing. doi: Io.I787/Idobc92a-en

OECD. (20I9). Countries must make teaching profession more financially and intellectually attractive. Retrieved from https://www.oecd.org/education/countries-must-maketeaching-profession-more-financially-and-intellectually-attractive.htm

Owen, G. T. (20I4). Qualitative methods in higher education policy analysis: Using interviews and document Analysis. The Qualitative Report, Ig(26), I-I9. Retrieved from https://nsuworks.nova.edu/tqr/volig/iss $26 / 2$

PISA. (20I9). PISA 2021 ICT Framework. OCED 
Pricewaterhouse Coopers $\llbracket \mathrm{PwC} \rrbracket$. (20I6, August 17). Understanding the GCC education Sector: A country by country guide. Retrieved from

https://www.pwc.com/mI/en/industries/education/publications/educationcountry-profile-uae.pdf

Private Schools in the UAE. (20I7, March 7). Retrieved

fromhttps://government.ae/en/information-and-services/education/school-

education-k-12/joining-k-12-education/private-schools-in-the-uae

Ridge, N. Y., Shami, S., छ Kippels, S. M. (2016). Private education in the absence of a public option: The cases of the United Arab Emirates and Qatar. FIRE: Forum for International Research in Education, 3(2),pp. 4I-59. Retrieved from https://files.eric.ed.gov/fulltext/EJir330I5.pdf

Selwyn, N. (2014). Distrusting educational technology: Critical questions for changing times. New York: Routledge.

Stake, R. E. (2003). Case studies. In N. K. Denzin छ Y. S. Lincoln (Eds.), Strategies of qualitative inquiry (2nd ed.). London: SAGE.

Stake, R. E. (2005). Qualitative case studies. In N. K. Denzin छ Y. S. Lincoln (Eds.), The $S A G E$ handbook of qualitative research (p. 443-466). London: SAGE

Sustainable Development Goals. (2017). From goals to reality: UAE and the 2030 agenda for sustainable development. The UAE portal for the Sustainable Development Goals. Retrieved from https://uaesdgs.ae/UAESDGs/reportı/en/index.html\#2

Swain, C. (2006). Preservice teachers' self-assessment using technology: Determining what is worthwhile and looking for changes in daily teaching and learning practices.

Journal of Technology and Teacher Education, I4(I), 29-59

Tamim, R., Borokhovski, E., Pickup, D., छ Bernard, R. (2015). Large-scale, governmentsupported educational tablet initiatives. Commonwealth of Learning. doi: I0.I3I40/RG.2.I.2359.7849

Tondeur, J., Braak, J.V., Ertmer, P. A., \& Ottenbreit-Leftwich, A. (20I6). Understanding the relationship between teachers' pedagogical beliefs and technology use in education: A systematic review of qualitative evidence. Education Technology Research and Development65, pp. 555-57.doi: I0.1007/sII423-0I6-948I-2

Twining, P., Raffaghelli, J., Albion, P., छु Knezek, D. (2013). Moving education into the digital age: The contribution of teachers' professional development. Journal of Computer Assisted Learning, 29(5), 426-437

Ulrichsen, K. C. (20I6). The Gulf States in international political economy. DOI: I0.1057/978II373856II

United Arab Emirates Ministry of Education. (2020). Education 2020 Strategy. The UAE portal for the Sustainable Development Goals. Retrieved from https://u.ae/en/about-the-uae/strategies-initiatives-and-awards/federalgovernments-strategies-and-plans/education-2020-strategy 
United Arab Emirates Ministry of Education. (2020). Ministry of Education strategic plan 20I7-202I. (2020, October). Retrieved from https://www.moe.gov.ae/En/AboutTheMinistry/Pages/MinistryStrategy.aspx United Arab Emirates. (2010). UAEvision 202I. UAE: Author.

UNESCO. (2020). The futures of education after COVID-I9 regional dialogue synthesis report. Retrieved from

https://en.unesco.org/sites/default/files/synthesis_report_future_of_education_w ebnair_I.pdf

Webb, C. (2019). The innovation imperative: Adding fire to the fuel of genius in UAE schools? Paper presented to the Future of Education International Conference. Retrieved from https://conference.pixelonline.net/FOE/files/foe/edooo8/FP/4935-SOE3276-FP-FOE8.pdf

Wright, V. H. \& Wilson, E. K. (2005). From preservice to inservice teaching: A study of technology integration. Journal of Computing in Teacher Education, 22(2), 49-55 